\title{
Investigation of deformed wing virus, black queen cell virus, and acute bee paralysis virus infections in honey bees using reverse transcriptase-polymerase chain reaction (RT-PCR) method
}

\author{
Ayşegül USTA ${ }^{1, a, \unrhd}$, Yakup YILDIRIM ${ }^{1, b}$ \\ ${ }^{1}$ Burdur Mehmet Akif Ersoy University, Faculty of Veterinary Medicine, Department of Virology, Burdur, Türkiye \\ aOORCID: 0000-0002-8376-0421; ' $\mathrm{ORCID:} \mathrm{0000-0003-4299-4712}$ \\ Corresponding author: aysglst6@gmail.com \\ Received date: 16.11.2020 - Accepted date: 02.07.2021
}

\begin{abstract}
Viruses are one of the most potential risk factors that negatively affect the different life stages of honey bees. This study was conducted to determine the presence of infections caused by the deformed wing virus (DWV), black queen cell virus (BQCV), and acute bee paralysis virus (ABPV) in honey bees in the beekeeping regions of Burdur, along with obtaining information about their prevalence in this particular region. In our study, the adult bees were taken from 31 different beehives and comb samples that had different honey bee breeds and were sampled randomly from 15 beekeeping areas within the region. The collected samples were analyzed using the reverse transcriptase-polymerase chain reaction (RT-PCR), and the prevalence of DWV, BQCV, and ABPV infections were determined to be $74.19 \%$ (23/31), 25.81\%, (8/31) and 74.19\% (23/31), respectively. In this study, the distribution of positive samples and the rates of multiple infections were determined in the colonies. Of the positive honey bee samples, $12(\% 38.71)$ were detected only for one virus, 9 (\%29.03) were positive for two viruses (DWV-ABPV) and $8(\% 25.81)$ were positive for all three viruses. In the present study, the presence of the three bee viruses that caused significant damage to the colonies by multiple infections in the Burdur region was determined with RT-PCR. To our knowledge, this is the first report of three mentioned bee infections in honey bees in the Burdur region. The revealed epidemiological conditions lead to the conclusion that serious measures are needed to control these infections in this region.
\end{abstract}

Keywords: Acute bee paralysis virus, black queen cell virus, deformed wing virus, honey bee, RT-PCR.

\section{Bal arılarında deforme kanat virus, siyah kraliçe hücre virus ve akut arı felci virus enfeksiyonlarının reverz transkriptaz-polymerase chain reaction (RT-PCR) metodu kullanılarak araştırılması}

Özet: Viruslar bal arılarının farklı yaşam evrelerini olumsuz yönde etkileyen potansiyel risk faktörlerinden birisidir. Bu çalışma, Burdur yöresinde arıcılık işletmelerinde bulunan bal arılarında deforme kanat virus (DKV), siyah kraliçe hücre virus (BKHV) ve akut arı felci virus (AAFV) enfeksiyonlarının varlığının virolojik olarak saptanması ve bu yöredeki yaygınlıkları hakkında bilgi edinilmesi amacıyla yapılmıştır. Araştırmada söz konusu yörede bulunan 15 arıcılık işletmesinden tesadüfi örnekleme ile farklı arı ırklarından 31 farklı kovandan ergin arı ve yavrulu petek örneği usulüne uygun olarak alındı. Toplanan numuneler reverse transcriptase-polymerase chain reaction (RT-PCR) metodu ile analiz edildi ve DKV, BKHV, AAFV enfeksiyonlarının prevalans1 sırasılla \% 74,19 (23/31), \%25,81 (8/31), \%74,19 (23/31) oranlarında belirlendi. Çalışmanın yürütüldüğü kolonilerde tespit edilen pozitifliğin ırklara göre dağılımı ve çoklu enfeksiyon oranları tespit edildi. Pozitif örneklerin 12'si (\%38,71) sadece bir virusa, 9'u (\%29,03) iki virusa (DKVAAFV) ve 8'ide $(\% 25,81)$ üç virusa karş1 pozitif bulundu. Bu çalışmada Burdur yöresinde çoklu enfeksiyonlarla kolonilercde önemli hasara neden olan üç arı virusunun varlığı RT-PCR ile belirlendi. Bu çalışma, Burdur bölgesindeki bal arılarında adı geçen üç virusun varlığına ilişkin bilinen ilk raporu sunmaktadır. Tespit edilen epidemiyolojik sonuçlara göre yörede bu enfeksiyonların kontrolü amacıyla ciddi önlemlerin alınması gerektiği kanaatine varıldı.

Anahtar sözcükler: Akut arı felci virus, bal arısı, deforme kanat virus, siyah kraliçe hücre virus, RT-PCR.

\section{Introduction}

Viruses are one of the most potential risk factors that negatively affect the different life stages of honey bees. About 26 honey bee viruses have been reported so far in the literature $(16,27,40)$. Many studies conducted in beekeeping have shown that the deformed wing virus (DWV), black queen cell virus (BQCV), and acute bee paralysis virus (ABPV) are the main viruses causing 
heavy losses in bees $(41,43,44)$. The viral nucleic acid of DWV is a single-stranded positive polarity RNA $(25,28)$, and the structure is approximately $10.1 \mathrm{~kb}$ long. The DWV virus belongs to the Iflavirus genus of the Iflaviridae family. Iflaviruses differ from the dicistroviruses through a single ORF region present in their genome (45). The deformed wing virus of honeybees is closely associated with characteristic wing deformities, paralysis, abdominal bloating, and rapid mortality of emerging adult bees (25).

The Varroa destructor is a major vector for DWV. This ectoparasitic mite receives the virus through the hemolymph of the infected bee and transmits the virus while feeding on another bee. DWV can be transmitted across bee colonies through both vertical and horizontal transmission. Vertical transmission takes place through drone sperm and queen bee eggs while horizontal transmission takes place through larval foods $(9,33,48$, 49). DWV causes colony effects such as bee deformity, malformed appendages (crumpled/vestigial wings), shortened abdomen, weight loss $(11,38)$, a probable decline in lifespan (23), and consequently irregular and decreased bees (40).

BQCV is the most common (approximately 80\%) honey bee virus, followed by the deformed wing and sacbrood viruses (43). It is an RNA virus that belongs to the Triatovirus genus of the Dicistroviridae family (42). This virus has a non-enveloped structure with cubic symmetry and carries a single-stranded positive polarity nucleic acid (ssRNA) (26). Being an etiological agent of a fatal disease in honeybee queen larvae and pupae, the BQCV infection is observed on the sealed cell wall of the queen's pupa along with the presence of dead pupae (5). The Nosema apis and Nosema ceranae microorganisms act as a vector in the epidemiology of the BQCV infection $(1,4,7,44)$. Also, the transmission may occur through feeding or contaminated foods (2). BQCV is one of the most common but least known honey bee pathogens, with the most common clinical symptoms consisting of blackened cells and the death of queen larvae or pupae (42). It is observed that the dead pupae in the cell take up a dark color and appear brownish to black. Simultaneously, the blackening of the cell wall occurs on the larvae and pupae as well. This virus causes diarrhea in adult bees (28), where the infected queen bee becomes weak and contaminated (14).

Acute bee paralysis is frequently seen in honey bees and is one of the causes of collapsing colonies. Acute bee paralysis virus (ABPV) is an RNA virus that belongs to the Aparavirus genus of the Dicistroviridae family (12). It has a cubic symmetry and non-enveloped structure that carries single-stranded viral nucleic acid (ssRNA) (46).

The disease caused by ABPV can be seen across all the biological phases of honey bees. In its natural condition, the virus spreads through the oral secretions (royal jelly) of infected adult bees, which are transmitted to young pupal bees during the feeding process. Bees display the symptoms of the viral disease through their feces. The parasitic mite $V$. destructor is the vector of this virus (30). Depending on the ABPV infection, acute or subclinical diseases are formed in bees. Symptoms and deaths connected to acute bee paralysis occur mostly in colonies infested with Varroa mites. Adult bees show symptoms of paralysis as trembling after 5-6 days of incubation. Progressively, some of the bees may appear dark and hairless, while flightless honey bees die within 1-2 days (28). The incidence of the ABPV infection varies in different countries based on their colony capacities and Varroa control programs.

Although there is a considerable amount of honey bee population in our country and the world, the data on bee viruses is a limited reference. This study aimed to determine the presence, prevalence, and distribution rates of the bee colonies infected with the DWV, BQCV, and ABPV, causing significant colony losses in the Burdur region using the RT-PCR method.

\section{Materials and Methods}

Samples and isolation procedure: In this study, sampling was carried out between June and September 2019 within the Burdur region. The sample size was calculated at a $90-95 \%$ confidence interval to determine the number of samples in this research (13). Thirty-one (from 15 apiaries) adult bees and pupa samples were taken from beehives and brought to the laboratory in the cold chain. The collected honey bee samples consisted of different races, including ten Anatolian races (five Muğla ecotypes and five Ege ecotypes), three Syrian, two Belfast, seven Italian, two Carpathian, and seven Carniolan races.

The presence of a clinically deformed wing in some honey bees was observed during our field studies (Figure 5). Also, all honey bees were checked during the laboratory stage of the research for Varroa mites under a stereomicroscope.

Twenty adult bees and honeycomb samples were grouped in each sample. The samples were homogenized in a sterile mortar with 4-5 mL of phosphate buffer saline (PBS) along with $1000 \mu \mathrm{g}$ of streptomycin and $1000 \mathrm{IU}$ of penicillin per $\mathrm{mL}$. Following this process, the samples were transferred to $15 \mathrm{~mL}$ sterile tubes and centrifuged for $30 \mathrm{~min}$ at $4000 \mathrm{rpm}$. Supernatants were stored at $-80{ }^{\circ} \mathrm{C}$ until further extraction of RNA.

RNA extraction and reverse transcriptionpolymerase chain reaction (RT-PCR): Total RNA extraction was performed by placing the supernatants obtained from homogenate samples into the automatic extraction appliance (Roche, Magna Pure, Germany). The 
obtained 31 supernatants were further used for the experiment, out of which $200 \mu \mathrm{L}$ was used for each bee sample. RNA samples, thus, obtained were stored at -80 ${ }^{\circ} \mathrm{C}$ until required for reuse. As per the procedure, a separate primary concentrate was prepared for all three viruses using a high pure viral nucleic acid kit elution buffer (no: 11858874001). Further, OneStep RT-PCR Kit (Grisp, Xpert OneStep RT-PCR Kit GK64.0100 Portugal) was used for reverse transcription, where the RT-PCR mix for each sample was prepared in a sterile Eppendorf tube as follows: $12.5 \mu \mathrm{L}$ of Fast PCR Master mix, $1 \mu \mathrm{L}$ each of forward GSP $(10 \mathrm{p} / \mathrm{mol})$ and reverse GSP $(10 \mathrm{p} / \mathrm{mol}), 5 \mu \mathrm{L}$ of extracted RNA sample, $1.25 \mu \mathrm{L}$ of RTase Mix, and 4.25 $\mu \mathrm{L}$ of RNase-free water.

RT-PCR was performed using specific primers for the VP1-VP2 gene of DWV, the VP3 gene of BQCV, and the VP2 gene for ABPV. The specific primers are shown in Table 1. The thermal cycling conditions were as follows: one cycle for reverse transcription at $45{ }^{\circ} \mathrm{C}$ for 10-15 min followed by initial denaturation at $95^{\circ} \mathrm{C}$ for 3 min. Then, 35 cycles of denaturation step at $95{ }^{\circ} \mathrm{C}$ for 10 sec, annealing at $56^{\circ} \mathrm{C}$ for $10 \mathrm{sec}$, and finally an extension step at $72{ }^{\circ} \mathrm{C}$ for $15 \mathrm{sec}$ with a final extension of one cycle at $72{ }^{\circ} \mathrm{C}$ for $1 \mathrm{~min}$. The annealing temperature used to amplify all the viruses was the same. Viral RNA was amplified using the Techne TC-412 device.

We used the positive RNA controls from the Izmir Bornova Veterinary Control Institute to achieve optimization in PCR. The products were electrophoresed on a $1.5 \%$ agarose gel containing ethidium bromide and then visualized under a UV transilluminator.
Varroa destructor determination: The honey bees brought to the laboratory were analyzed for the presence of Varroa mite. The average size of the mature Varroa mites is $1.2 \mathrm{~mm}$ while the width is $1.6 \mathrm{~mm}$, and the male mite's size is smaller than the size of the female mite. Mature female Varroa mites are reddish brown, but male mites are tan in color $(21,30)$. The sedimentation method was used to separate the Varroa from the wastes of the hive wood floor. One part of waste was mixed with 10 parts of oil. Varroa mites that accumulated on the surface of the oil were collected after the waste had precipitated. The bees were placed in jars of warm water at $8-12^{\circ} \mathrm{C}$ to gain a clear result and one drop of detergent was dropped on them. The honey bees were then examined for Varroa mite approximately 5-10 min. after being removed from the jars (21).

\section{Results}

The prevalence of all three viruses among the 31 samples collected from 15 apiaries is shown in Table 2. Based on the results of the viral-specific PCRs, out of 31 samples, twenty-three $(74.19 \%)$ were found to be coinfected with DWV and ABPV, while eight (25.81\%) were found to be positive for BCQV nucleic acid. As predicted, the DWV primers amplified a $269 \mathrm{bp}$ fragment from the VP1-VP2 gene of DWV, while a $460 \mathrm{bp}$ amplicon was amplified from the VP2 gene of ABPV and 536 bp amplicon was obtained from the VP3 gene of BQCV. The gel images obtained from the RT-PCR results are presented in Figures 1, 2, and 3.

Table 1. Primers used for all three viruses and the size of their amplicons.

\begin{tabular}{llccc}
\hline Primer & Nucleotide sequences & Target gene & Product length (bp) & Reference \\
\hline DWV-F & TGGTCAATTACAAGCTACTTGG & VP1-VP2 & $269 \mathrm{bp}$ & 39 \\
DWV-R & TAGTTGGACCAGTAGCACTCAT & & & 39 \\
BQCV-F & CTTTATCGAGGAGGAGTTCGAGT & VP3 & $536 \mathrm{bp}$ & \\
BQCV-R & GCAATAGATAAAGTGAGCCCTCC & & & 39 \\
AIV-F & GGTGCCCTATTTAGGGTGAGGA & VP2 & $460 \mathrm{bp}$ & \\
ABPV-R & ACTACAGAAGGCAATGTCCAAGA & & & \\
\hline
\end{tabular}

Table 2. Prevalence distribution of all three viruses based on the bee races.

\begin{tabular}{lccc}
\hline Bee race & Number of samples & DWV (+)/\% & BQCV (+)/\% \\
\hline Muğla & 5 & $5 / 100$ & $3 / 60$ \\
Syria & 3 & $3 / 100$ & - \\
Belfast & 2 & $2 / 100$ & - \\
Italian & 7 & $5 / 71.43$ & $1 / 33.33$ \\
Carpathian & 2 & $2 / 100 / \%$ & $1 / 50$ \\
Ege & 5 & $4 / 80$ & $7 / 100$ \\
Carniole & 7 & $2 / 28.57$ & $2 / 46$ \\
\hline Total & $\mathbf{3 1 ~ S a m p l e s}$ & $\mathbf{2 3 / 7 4 . 1 9}$ & $2 / 40$ \\
\hline
\end{tabular}




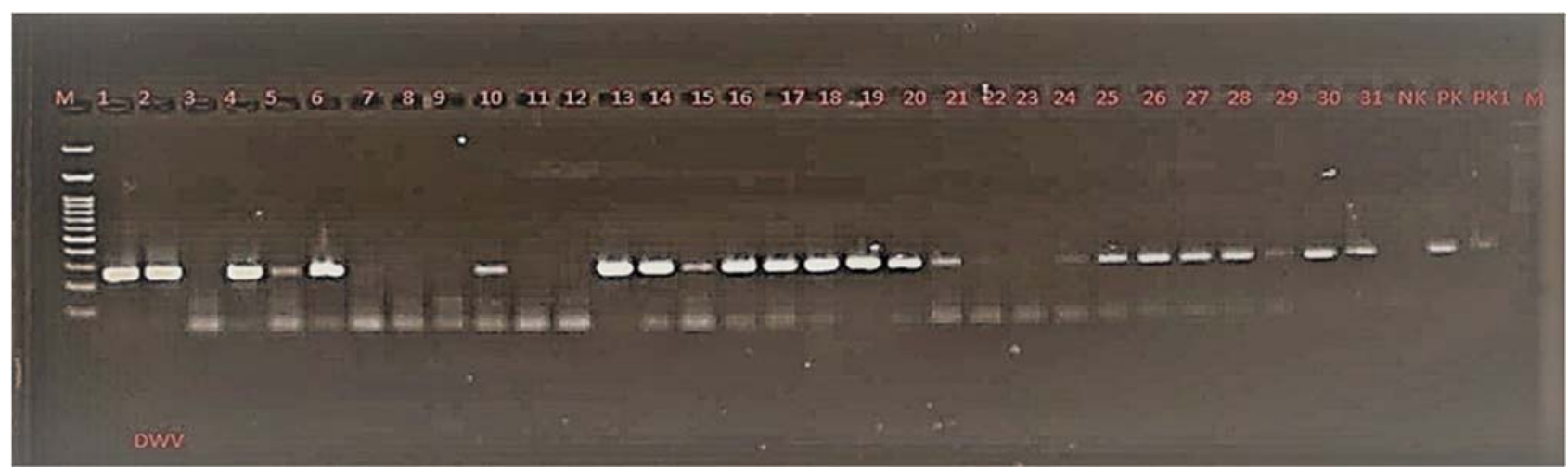

Figure 1. DWV RT-PCR gel image [M: Marker, 1-31: Samples, NK: Negative Control, PK: Positive Control, PK1: Positive control] (269 bp).

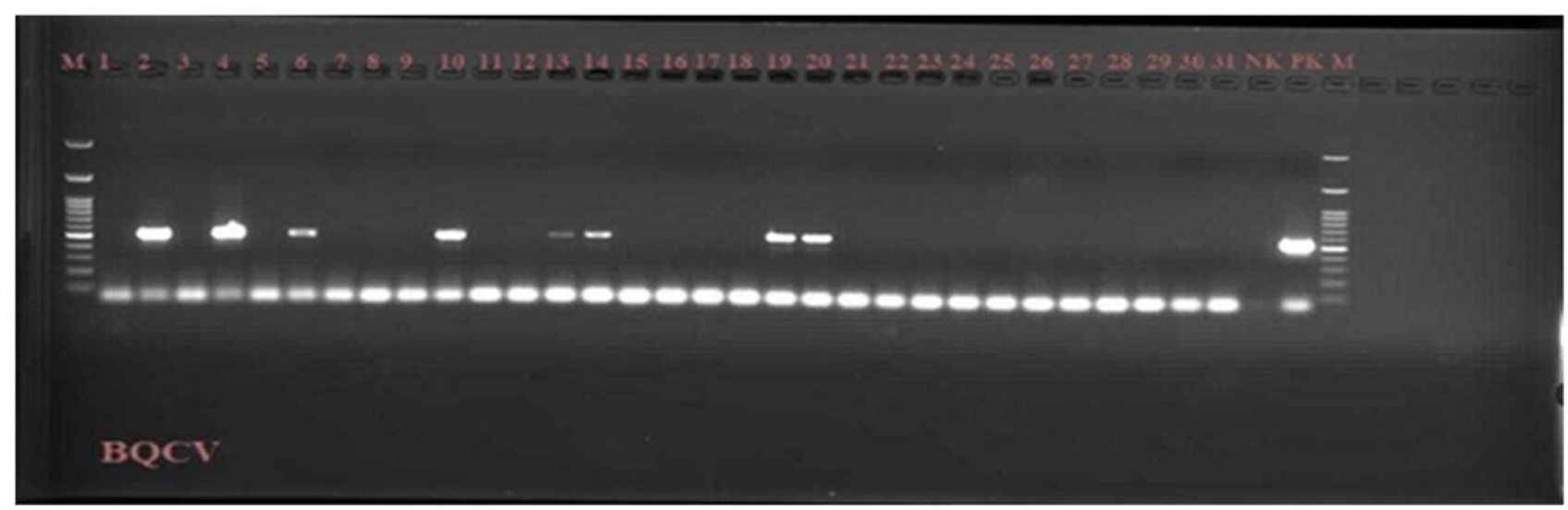

Figure 2. BQCV RT-PCR gel image [M: Marker, 1-31: Samples, NK: Negative Control, PK: Positive Control] (536 bp).

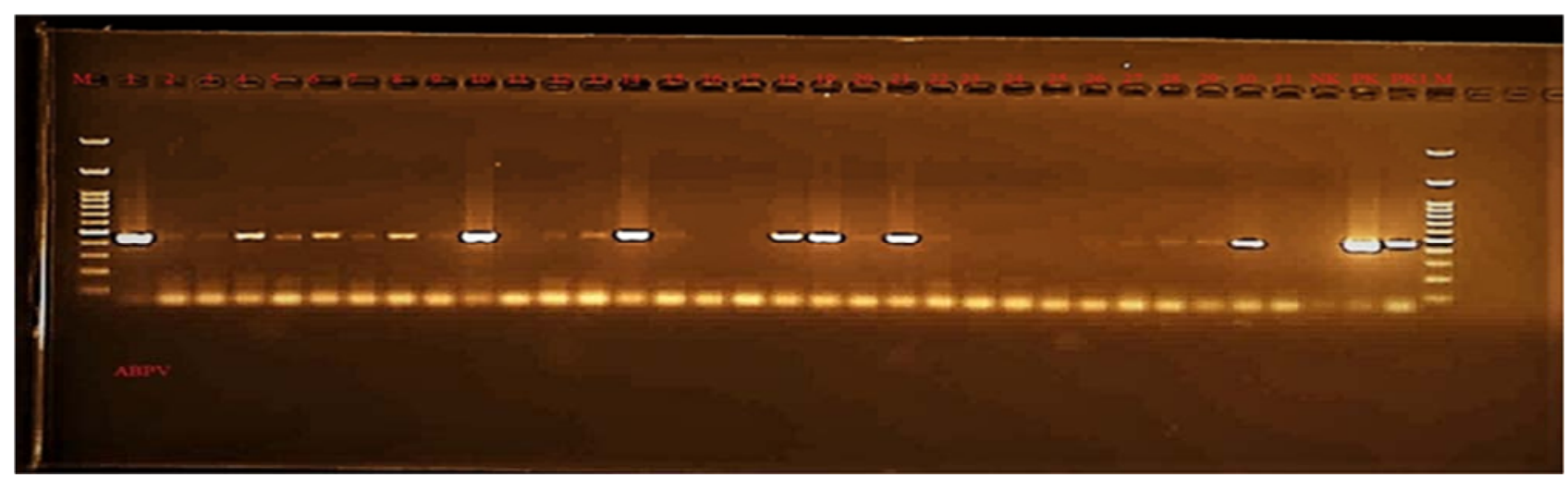

Figure 3. ABPV RT-PCR gel image [M: Marker, 1-31: Samples, NK: Negative Control, PK: Positive Control, PK1 Positive control] (460 bp).

The distribution of the resultant data was evaluated according to the races and is as follows: twenty-three DWV positive samples were observed in the Anatolian race of Muğla ecotype, four in the Anatolian race of Ege ecotype, three in Syria, two in Belfast, five in Italian, two in Carpathian and two in Carniole bee races, respectively. Out of the eight BQCV positive samples, three were determined to be of the Anatolian race of Muğla ecotype, two were from the Anatolian race of Ege ecotype, and three were from the Italian bee race. Out of twenty-three
ABPV positive samples, five were found to be of the Anatolian race of Muğla ecotype, two were of the Anatolian race of Ege ecotypes, one of Syrian and Belfast races, seven of the Italian race, five of Carniole, and two were of the Carpathian bee race (Table 2).

Positive results were evaluated in the colonies in terms of DWV, BQCV, and ABPV, with multiple infection rates also being determined. When the distribution of study data by race is evaluated; $23 \mathrm{DWV}$ positive samples; have been observed in Muğla, 4 in Ege 
ecotype, 3 in Syria, 2 in Belfast, 5 in Italian, 2 in Carpathian and 2 in Carniole, respectively. $8 \mathrm{BQCV}$ positive for example; 3 of them were determined in Muğla, 2 of them in Ege ecotype and 3 of them in Italian bee race. 23 ABPV positive samples were found to be 5 in Muğla, 2 in Ege ecotypes, 1 in Syria and Belfast, 7 in Italian, 5 in Carniole and 2 in the Carpathian bee race (Table 2).

In addition, positive results in terms of DWV, BQCV and ABPV were evaluated and multiple infection rates in colonies were determined. When these results were evaluated, $2(6.45 \%)$ honey bee samples were found negative for all the viruses controlled. Of the positive honey bee samples, $12(38.71 \%)$ were detected only for one virus, $9(29.03 \%)$ were positive for two viruses (DWV-ABPV) and 8 (25.81\%) were positive for all three viruses (Figure 6).

The obtained samples were identified as Varroa destructor by morphological analysis (Figure 4).
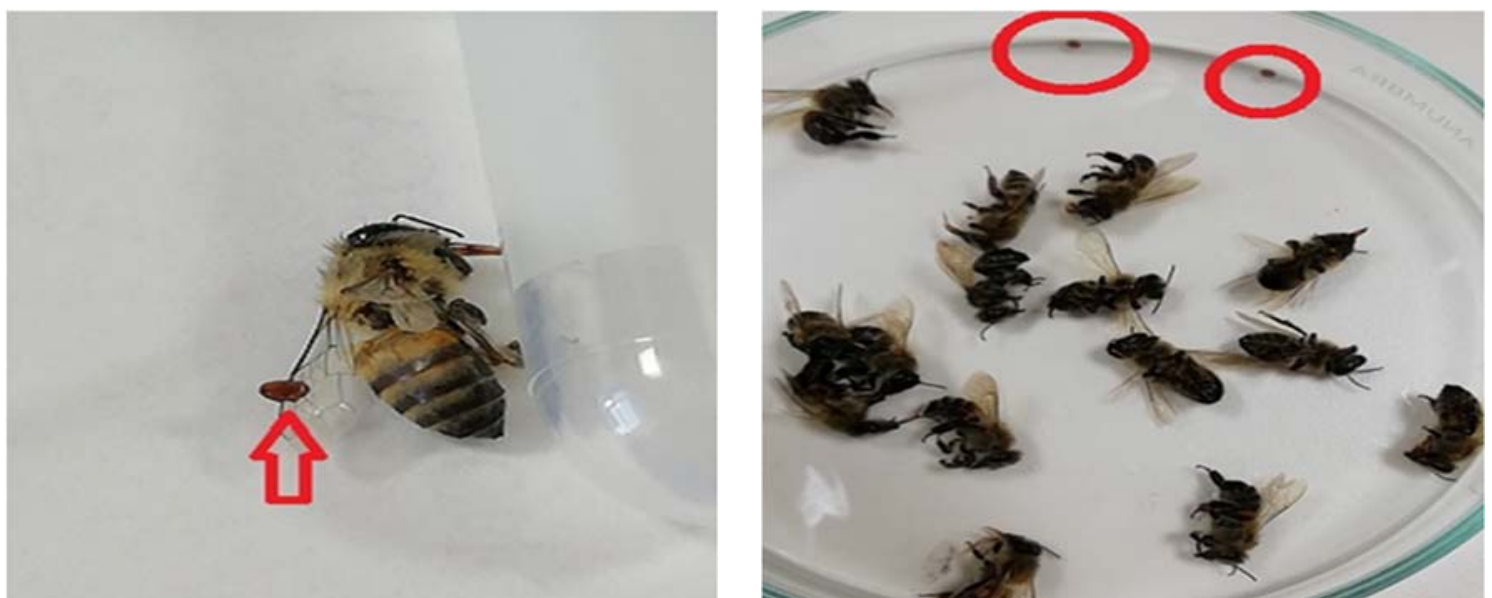

Figure 4. Varroa spp.-infested bee samples encountered during the research are marked with red signs (Original).
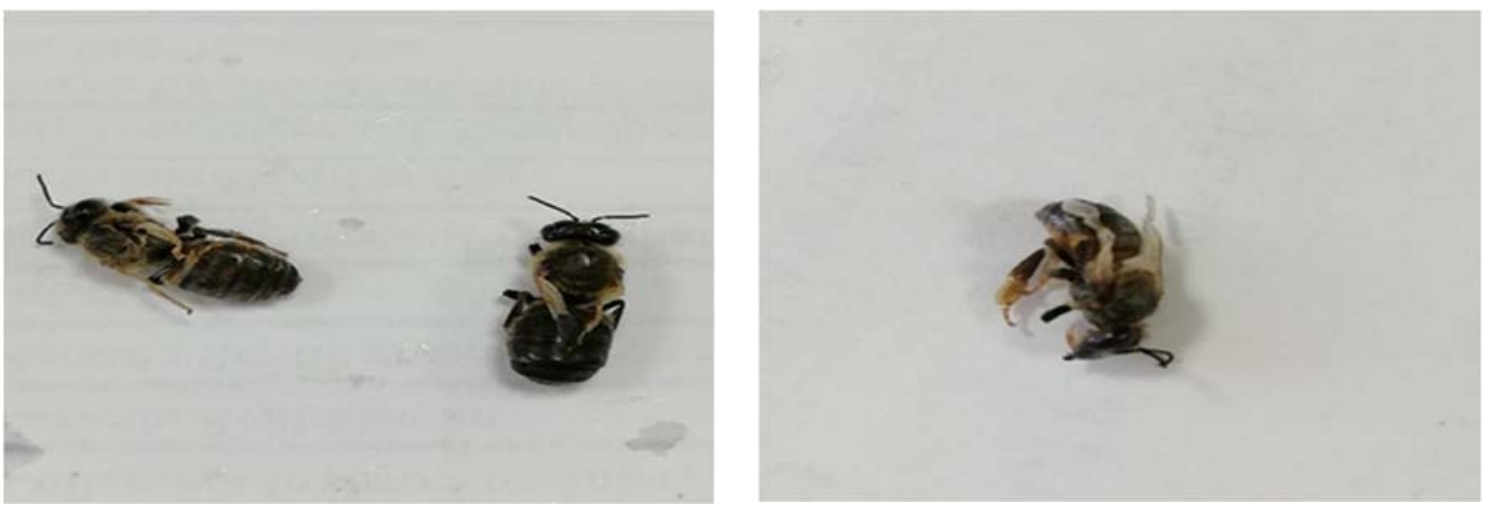

Figure 5. Images with deformed wings detected in bees at some sampled apiaries (Original).

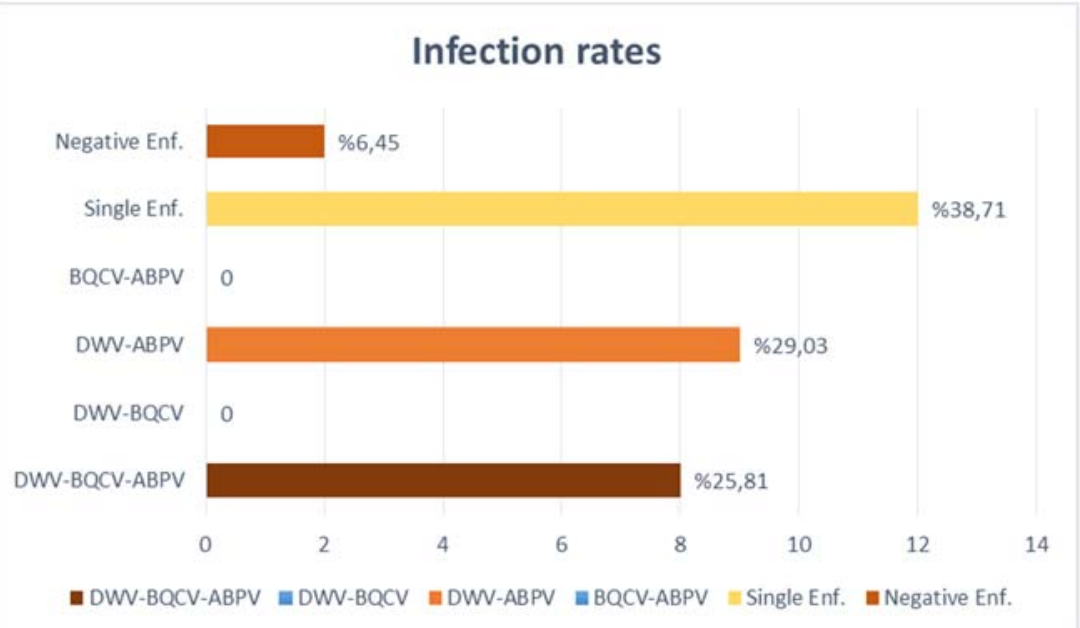

Figure 6. Multiple infections were observed in the controlled colonies. 


\section{Discussion and Conclusion}

Honey bee products such as royal jelly, honey, and pollen are very valuable in terms of nutrition and health and also in the industries. Additionally, bees are critical for the continuity of the ecosystem. Therefore, it is very important to protect the health of honey bees and protect them against diseases. Especially, it is essential to prevent the unexplained colony losses in beehives or minimize the losses for the future and continuation of our world $(3,7$, 18, 29).

The existence of healthy bees and bee colonies in our country and the world is very important in terms of both natural life and human health. One of the most important criteria is to raise the bees and their colonies free from the viral agents. Hence, it is necessary to conduct accurate and rapid diagnoses along with combating these diseases by proper protection measures in place. In this way, we can protect the health of honey bees and contribute to future generations and the ecosystem $(17,20,31,36,44)$. Difficulties are encountered while assessing the epidemiological status of countries because it is not compulsory to report the DWV, ABPV, and BQCV infections in disease reporting systems such as Animal Disease Notification System (ADNS) and World Organization for Animal Health (OIE). However, when the literature related to these viruses was examined, the diseases were observed to be spread worldwide. Depending on the honey bee colony capacities of various countries and the Varroa struggle programs, the incidence of these infections varies between $2 \%$ and $91 \%(3,30,34$, 44, 47).

DWV causes unusually high winter deaths and disease symptoms and is detected at high prevalence in adults and pupae in many countries using molecular diagnostic techniques such as RT-PCR methods $(3,6,15$, 24, 31). The prevalence of DWV in the world is as described below: the most common honey bee virus is found in Thailand (37) and is closely related to the infestation of Varroa (8) and Tropilaelaps mites (22). A study conducted in Germany showed that all German bees infested by the endemic Varroa destructor parasite species were compared with the Swedish bees brought from Sweden. However, this Varroa mite has not been reported to date. The German bees were $100 \%$ positive for the DWV nucleic acid, while only $40 \%$ of Swedish bees were positive for DWV (50). A study was carried out using the RT-PCR method in the Aclun region of Jordan, where there were losses observed in the bee colonies, and it was determined that there was a high rate of DWV in these colonies (19). Shumkova et al. (41) reported the prevalence of DWV in the bee colonies of Bulgaria at a rate lower than that found in other countries. In the study conducted on honey bees located in different climatic regions of Argentina, 35\% of the colonies were found to be DWV positive. However, in the same study, approximately $25 \%$ of the bees showed binary and triplet viral infections (30).

Many studies have been conducted in our country related to DWV. One study was conducted in the queen bee colonies, where approximately $50 \%$ of the hives were reported to be infected with this virus (17). Karapınar et al. (21) detected a high rate of DWV disease, i.e., 69.23\% in the province of Van, which was also similar to the prevalence of Varroa parasite in these colonies. A largescale study was conducted in apiaries in the Aegean region which used the multiplex RT-PCR method and determined the DWV rate to be $25.2 \%$. Especially in some apiaries, where there were DWV disease symptoms or high colony loss, the prevalence of viral agents was reported to be higher in the bee population (10). Rüstemoğlu also reported the prevalence of DWV at a rate of $23.3 \%$ in a total of 90 apiaries collected from Hakkari province in 2015, which was conducted on the bee samples using the RT-PCR method (36). Kalayc1 et al. reported that DWV was the most prevalent virus in the Turkish apiaries with a rate of $44.7 \%(20)$.

In this study, DWV was detected in twenty-three (74.19\%) of 31 samples collected from 15 apiaries. Our results were parallel with those obtained by Karapınar et al. (21). But, our percentage was found to be higher than the percentages found by Çağırgan (10), Kalaycı et al. (20), and Rüstemoğlu (36). The reason for high DWV prevalence may be attributed to this province being a transit/accommodation area for migratory beekeeping. Considering that the transmission of the virus happens through the Varroa mite, the evaluation that the Varroa destructor is seen on the bees in many sampled apiaries makes the fight against it not completely realized.

BQCV is one of the most common but least known honey bee pathogens, which causes a disease that leads to blackness and death of the queen, larvae, and pupae in high titers (42). The prevalence of BQCV in Uruguay was found to be $91 \%$ using the RT-PCR method in the bee colonies, while the research was being reported as the first case of BQCV in South America (3). Tentcheva et al. (44) screened 36 adult bees and pupa samples collected from apparently healthy colonies during the spring, summer, and autumn seasons using the RT-PCR method and found $86 \%$ positive BQCV colonies. A study conducted in Denmark (31) revealed the presence of BQCV in the colony where winter deaths were unusually high. In Australia, $65 \%$ of the bee colonies were reported to be BQCV positive (33). Also, the BQCV infection was found at a high prevalence $(81 \%)$ in Chile province in South America (35). However, another research was conducted by the same researchers in Chile in the following years, 
which showed the prevalence of infection to be decreased by $10 \%$ (34). However, in the studies conducted in England, Croatia, and Syria, the prevalence of BQCV was reported to be of a lower rate $(6,15,24)$.

In terms of the studies related to BQCV infection in our country, Gümüşova et al. observed higher BQCV positive rates in adult bees (53\%) compared to the larvae (33\%) using the RT-PCR method in 2010 (18). Oğuz et al. reported the presence of $\mathrm{BQCV}$ nucleic acid in the bees of the Van province at a rate of $88.5 \%$ using the RT-PCR method, which was sampled during April and May 2017 (32). In another study conducted in the same province, BQCV was found to be positive in $88.46 \%(23 / 26)$ of the sampled hives. In a study conducted using the multiplex RT-PCR method in apiaries in the Aegean region, the BQCV infection rate was determined to be $25.2 \%$ in the bees (10). Rüstemoğlu determined the rate of positive BQCV as $32.2 \%$ in the bee samples collected from Hakkari province in 2015 (36).

In our study, the presence of BQCV nucleic acid was detected in eight $(25.81 \%)$ samples out of 31 bee samples collected from the Burdur region. This rate is lower than the positive rates found in the black sea and eastern provinces of our country $(18,32,36)$. However, the $\mathrm{BQCV}$ positive rates in our results were corresponding exactly with the rate determined in the Aegean region (10), which is also closer to our area of study. The reason for the lower rate of BQCV-positive bee colonies in our study compared to the DWV and ABPV infections was attributed to the low rate of Nosema infection in bee colonies in our area.

Although ABPV presence was not detected in eastern bee colonies of China's Yunnan province, its presence was reported as $2 \%$ in Chile and $9 \%$ in Uruguay (3, 34, 47). Also, the studies conducted in Europe determined ABPV positive rates to be higher $(6,15,31$, 44) and were accepted as one of the important causes of bee losses.

The presence of ABPV infections in Turkey was reported at different rates since the studies were conducted in different provinces. For the first time in our country, the presence of ABPV (2.2\%) was demonstrated using the RT-PCR method in bee samples collected from Hakkari (36). In the following years, Çağırgan (10) reported the prevalence of ABPV as 3.6\% in the samples collected from apiaries in the Aegean region while Karapinar et al. (21) did not observe any ABPV infection in their screening of bee colonies in Van province.

In this study, we determined the prevalence of ABPV in the Burdur region to be at the rate of $74.19 \%$. Compared to the other studies conducted in Turkey, our work in the beehive indicated the reason for a high rate of ABPV infection in the bee colonies, commonly consisting of $V$. destructor infestations. An increase in the spread of infectious agents was attributed to the fact that the Burdur region is an accommodation/transit area for migratory beekeeping. Additionally, in our study, varroasis was observed in all of the sampled bees. This is an important finding in terms of the epidemiology of viral pathogens transmitted by the Varroa vector.

Honeybee colonies are commonly infected by many viruses simultaneously, often without exhibiting overt signs $(15,28)$. Mixed viral infections were detected in honeybee samples, which were shown in Figure 6. These results were consistent with those obtained by Kalayc1 et al. (20) and Çağırgan (10). Our mixed viral infection ratios were $25.81 \%$ and $29.03 \%$, which might indicate the presence of colony losses in this study. But in all cases, multiple viral infections were observed simultaneously along Varroa. Also, multiple factors may have led to colony collapses depending on the quality of nutrition and pathogens/pathogen titers.

In conclusion, the data of this research revealed a very high prevalence of pathogenic viruses in the bee population of the Burdur province, which was thought to be the probable reason for the loss of colonies in the hives of Burdur. It is required to detect and use bee breeds to protect the health of the bees that are resistant to viral disease. Also, feeding/hosting conditions, compliance with sanitation, and hygienic measures should not be ignored. In addition to these, it may be beneficial to carry out screening/struggle programs for viral and parasitic factors to protect bees' health. We conclude that conducting regional and national major studies along with serious measures to protect the bees against viral diseases is very important for animal health and our country's economy and ecosystem.

\section{Acknowledgments}

We thank Dr. A. Anıl Çağırgan and İzmir/Bornova Veterinary Control Institute for their contributions. This study represents part of the thesis submitted by A. Usta to the Virology Department of Veterinary Medicine Faculty of Burdur Mehmet Akif University, Burdur, Turkey, to fulfill the requirements for a master's degree in veterinary medicine.

\section{Financial Support}

This research was supported by Burdur Mehmet Akif Ersoy University Scientific Research Projects Unit with project number 0586-YL-19.

\section{Ethical Statement}

This study was approved by the Burdur Mehmet Akif Ersoy University Animal Experiments Local Ethics Committee (2019-61-493). 


\section{Conflict of Interest}

The authors declared that there is no conflict of interest.

\section{References}

1. Allen MF, Ball BV (1996): The incidence and World distribution of honey bee viruses. Bee World, 77, 141-162.

2. Anderson D (2005): Triggering virus replication in honey bees. Bee Research And Virus in Europe. 24-26. In: Proceedings of the meeting in Sophia-Antipolis, France.

3. Antúnez K, D'Alessandro B, Corbella E, et al (2006): Honey bee viruses in Uruguay. J Invertebrat Pathol, 93, 6770.

4. Bailey L, Ball BV, Perry JN (1983): Association of viruses with two protozoal pathogens of the honey bee. Ann of Appl Biol, 103, 13-20.

5. Bailey L, Woods RD (1977): Two more small RNA viruses from honey bees and further observations on sacbrood and acute bee-paralysis viruses. J Gen Virol, 37, 175-182.

6. Baker AC, Schroeder DC (2008): Occurrence and genetic analysis of picorna-like viruses infecting worker bees of Apis mellifera L. populations in Devon, South West England. J Invertebr Pathol, 98, 239-242.

7. Berényi O, Bakonyi T, Derakhshifar I, et al (2006): Occurrence of six honey bee viruses in diseased Austrian apiaries. Appl Environ Microbiol, 72, 2414-2420.

8. Chantawannakul P, Ward L, Boonham N, et al (2006): A scientific note on the detection of honey bee viruses using real-time PCR (TaqMan) in Varroa mites collected from a Thai honey bee (Apis mellifera) apiary. J Invertebr Pathol, 91, 69-73.

9. Chen YP, Evans J, Feldlaufer M (2006): Horizontal and vertical transmission of viruses in the honey bee (Apis mellifera). J Invertebr Pathol, 92,152-159.

10. Çağırgan AA (2018): Ege Bölgesinde Virus Nedenli Arı Hastalıklarının Multipleks Polimeraz Zincir Reaksiyonu İle Araştırılması. Doktora Tezi. Ondokuz Mayıs Üniversitesi Sağlık Bilimleri Enstitüsü, Samsun.

11. De Jong D, De Jong PH, Gonçalves LS (1982): Weight loss and other damage to developing worker honey bees from infestation with Varroa jacobsoni. J Apic Res, 21, 165167.

12. De Miranda JR, Cordoni G, Budge G (2010): The Acute bee paralysis virus-Kashmir bee virus-Israeli acute paralysis virus complex. J Invertebr Pathol, 103, 30-47.

13. Erganiş O (1993): Veteriner Epidemiyoloji (Temel Bilgiler). 74-79. Mimoza Yayınları:16, Sağlık Bilimleri Dizisi: 2, Konya.

14. Fievet J, Tentcheva D, Gauthier G, et al (2006): Localization of deformed wing virus infection in queen and drone Apis mellifera L. Virol J, 3, 16.

15. Gajger I, Kolodziejek J, Bakonyi T, et al (2014): Prevalence and distribution patterns of seven different honey bee viruses in diseased colonies: a case study from Croatia. Apidologie, 45, 701-706.

16. Garigliany M, Agrebi NE, Franssen M, et al (2018): Moku virus detection in honey bees Belgium, 2018. Wiley Transbound Emerg Dis, 66, 43-46.

17. Gülmez Y, Bursalı A, Tekin Ş (2009): First molecular detection and characterization of Deforme dwing virus
$(D W V)$ in honey bee (Apis melifera) in Turkey. African $\mathrm{J}$ Biotechnol, 8, 3698-3702.

18. Gümüşova SO, Albayrak H, Kurt M, et al (2010): Prevalence of three honey bee viruses in Turkey. Veterinarski Arhiv, 80, 779-785.

19. Haddad N, Brake M, Migdadi H, et al (2008): First detection of honey bee viruses in jordan by Rt-Pcr. Jordan $\mathrm{J}$ Agricul Sci, 4, 3.

20. Kalaycı G, Cagırgan AA, Kaplan M, et al (2020): The Role of Viral and Parasitic Pathogens Affected By Colony Losses in Turkish Apiaries. Kafkas Univ Vet Fak Derg, 26, 671-677.

21. Karapınar Z, Oğuz B, Dinçer E, et al (2018): Phylogenetic analysis of black queen cell virus and deformed wing virus in honey bee colonies infected by mites in Van, Eastern Turkey. Med Weter, 74, 460-465.

22. Khongphinitbunjong K, De Guzman LI, Tarver MR, et al (2015): Interactions of Tropilaelaps mercedesae, honey bee viruses and immune response in Apis mellifera. $\mathrm{J}$ Apic Res, 54, 40-47.

23. Kovac H, Crailsheim K (1988): Life span of Apis mellifera Carnica Pollm. infested by Varroa jacobsoni in relation to season and extent of infestation. J Apic Res, 27, 230-238.

24. Kubaa RA, Molınatto G, Khaled BS, et al (2018): First detection of black queen cell virus, Varroa destructor macula-like virus, Apis mellifera filamentous virus and Nosema ceranae in Syrian honey bees Apis mellifera syriaca. Bull Insectology, 71, 217-224.

25. Lanzi G, De Miranda JR, Boniotti MB, et al (2006): Molecular and biological characterization of deformed wing virus of honey bees (Apis mellifera L). J Virology, 80, 4998-5009.

26. Leat N, Ball B, Govan V, et al (2000): Analysis of the complete genome sequence of black queen-cell virus, a picorna-like virus of honey bees. Journal of General Virology, 81, 2111-2119.

27. Levin S, Sela N, Erez T, et al (2019): New Viruses from the Ectoparasite Mite Varroa destructor Infesting Apis mellifera and Apis cerana. Viruses, 11, 94.

28. Maramorosch K, Shatkin A (2007): Honey bee viruses. Advances in Virus Research, Academic Press, 33-80.

29. Molineri AI, Pacini A, Giacobino A, et al (2017): Prevalence of honey bee (Apis mellifera) viruses in temperate and subtropical regions from Argentina. Rev Argent Microbiol, 49, 166-173.

30. Moore PA, Wilson ME, Skinner JA (2015): Honey bee viruses, the deadly Varroa Mite Associates. Bee Health, 19, 2015.

31. Nielsen SL, Nicolaisen M, Kryger P (2008): Incidence of Acute bee paralysis virus, Black queen cell virus, Chronic bee paralysis virus, Deformed wing virus, Kashmir bee virus and Sacbrood virus in honey bees (Apis mellifera) in Denmark. Apidologie, 39, 310-314.

32. Oğuz B, Karapınar Z, Dinçer E, et al (2017): Molecular detection of Nosema spp. and black queen-cell virus in honey bees in Van Province, Turkey. Turk J Vet Anim Sci, 41, 221-227.

33. Roberts JMK, Anderson DL, Durr PA (2017): Absence of deformed wing virus and Varroa destructor in Australia provides unique perspectives on honey bee viral landscapes and colony losses. Sci Rep, 7, 6925. 
34. Rodríguez M, Vargas M, Antúnez K, et al (2014): Prevalence and phylogenetic analysis of honey bee viruses in the Biobío Region of Chile and their association with other honey bee pathogens. Chilean J Agricu, 74, 170-177.

35. Rodriguez M, Vargas M, Gerding M, et al (2012): Viral infeciton and Nosema ceranae in honey bees in Chile. $\mathrm{J}$ Apicul Res, 51, 285-287.

36. Rüstemoğlu M (2015): Hakkari İli Bal Arılarında (Apis Mellifera L.) Görülen Önemli Arı Viruslarının RT-PCR Yöntemi İle Araştırılması Ve Moleküler Karakterizasyonlarının Yapılması. Doktora Tezi. Van Yüzüncü Y1l Üniversitesi Fen Bilimleri Enstitüsü, Van.

37. Sanpa S, Chantawannakul P (2009): Survey of six bee viruses using RT-PCR in Northern Thailand. J Invertebr Pathol, 100, 116-119.

38. Schatton-Gadelmayer K, Engels W (1988): Hamolymphproteine und Korpergewicht frischgeschlupfter Bienen-Arbeiterinnen nach unterschiedlich starker Parasitierung durch Brutmilben. Entomol Gen, 14, 93-101.

39. Sguazza GH, Reynaldi FJ, Galosi CM, et al (2013): Simultaneous detection of bee viruses by multiplex PCR. J Virol Methods, 194, 102-106.

40. Shimanuki H, Calderone NW, Knox DA (1994): Parasitic mite syndrome: The symptoms. Am Bee J, 134, 827-828.

41. Shumkova R, Neov B, Sirakova D, et al (2018): Molecular detection and phylogenetic assessment of six honey bee viruses in Apis mellifera L. colonies in Bulgaria. Peer J, 20, 6:e5077.
42. Spurny R, Pridal A, Pálková L, et al (2017): Virion structure of black queen cell virus, a common honey bee pathogen. J Virol, 91, e02100-16.

43. Tapaszti Z, Forgach P, Kovágó C, et al (2009): Genetic analysis and phylogenetic comparison of Black queen cell virus genotypes. Vet Microbial, 139, 227-234.

44. Tentcheva D, Gauthier L, Zappulla N, et al (2004): Prevalence and Seasonal Variations of Six Bee Viruses in Apis mellifera L. and Varroa destructor Mite Populations in France. Appl Environ Microbiol, 7185-7191.

45. Valles SM, Chen YP, Firth AE, et al (2017): ICTV virus taxonomy profile: iflaviridae. J Gen Virolo, 98, 527-528.

46. Valles SM, Chen YP, Firth AE, et al (2017): ICTV virus taxonomy profile: dicistroviridae. J Gen Virolo, 98, 355356.

47. Wang M, Bi J, Wang L, et al (2016): Prevalence of Four Common Bee RNA Viruses in Eastern Bee Populations in Yunnan Province, China. J Veterinar Sci Technol, 7, 1.

48. Weinberg KP, Madel G (1985): The inxuence of the mite Varroa jacobsoni Oud. on the protein concentration and hemolymph volume of the blood of the worker bees and drones of the honey bee, Apis mellifera. Apidologie, 16, 421-436.

49. Yang X, Cox-Foster DL (2005): Impact of an ectoparasite on the immuni and pathology of an invertebrate: evidence for host immunosuppression and viral amplification. Proc Natl Acad Sci, 102, 7470-7475.

50. Yue C, Genersch E (2005): RT-PCR analysis of Deformed wing virus $(D W V)$ in honey bees (Apis mellifera) and mites (Varroa destructor). J Gen Virol, 86, 3419-3424. 